\title{
Misja rodziny wobec społeczeństwa w refleksji ks. profesora Jerzego Bajdy
}

Wstęp

Panowanie nad światem i budowanie społeczeństwa jest ściśle podporządkowane tajemnicy ludzkiego życia, objawiającej się w rodzinie niosącej $\mathrm{w}$ sobie transcendentne powołanie Boże $\mathrm{e}^{1}$. Ten rodzaj misji powinien być przeniknięty duchem personalizmu, zgodnie z którym osoba to indywidualna substancja natury rozumnej. Według św. Augustyna człowiek pozostaje największą tajemnica, nie jest samym ciałem ani samą duszą, lecz jest istota cielesno-duchową ${ }^{2}$.

Rodzina jest wartością nadrzędną, nie tylko źródłem, ale i obrońcą cenionych wartości, pełni
- Wstęp

- Rodzina szkołą życia

- Rodzina nauczycielką wychowania

- Rodzina transmisją tradycji

- Rodzina nauczycielką kultury

- Rodzina światem przekazu wartości - Podsumowanie

1 Por. J. Bajda, Rozmyślanie nad Listem do Efezjan (5, 28-33), „Ethos" 43 (1998) nr 3, s. 69.

2 S. Swieżawski, Dzieje europejskiej filozofii klasycznej, Wrocław 2000, s. 351-352. 
ważną rolę w kształtowaniu tożsamości społecznej dzieci i młodzieży. W społeczeństwie polskim przypisuje się jej ważną wartość i priorytetową rangę. Od funkcjonowania rodziny, od poziomu akceptacji rodziny przez jej członków, od procesów socjalizacji pierwotnej i wtórnej uzależniony jest kształt religijności, moralności oraz dalszy proces kształtowania postaw prospolecznych ${ }^{3}$.

Rodzina niewątpliwie jest także nauczycielką życia człowieka w społeczeństwie. Przez wybór określonych wartości człowiek tworzy własny porządek świata, kreując tym samym porządek otoczenia, który systematyzuje świat wartości człowieka. Zwykle ów system wartości podlega zmianom w zależności od sytuacji życiowej danej jednostki. W obecnych czasach nietrudno zauważyć kierunek tych zmian od wartości niematerialnych do materialnych, od religijnych do świeckich. Wypada w tym miejscu podać definicje rodziny w ujęciu Jerzego Bajdy. Jego zdaniem rodzina jest „komunią osób, w której objawia się i uobecnia początek istnienia człowieka, zanurzony w głębinach nieskończonej miłości Boga Ojca, objawionej w przyjściu Jednorodzonego Syna Bożego"4.

Misja rodziny wobec społeczeństwa jest niezwykła. Rodzina uczy i wychowuje. Ta droga edukacji stanowi jej fundament w zakresie przygotowania jednostki do życia w społeczeństwie. Zamysł napisania przedłożonego artykułu zrodził się właśnie w konwencji postrzegania rodziny jako szkoły życia, wychowania, przekazu tradycji, kultury i wartości.

\section{Rodzina szkołą życia}

Jednym z podstawowych zadań małżonków jest zrodzenie dzieci, czyli przekazanie życia warunkującego biologiczną wymianę pokoleń w społeczeństwie. Według Jerzego Bajdy ten warunek dotyczy odpowiedzi na antropologiczne pytanie: kim jest człowiek, który w imię powołania do miłości stał się uczestnikiem kosmicznej biosfery? Powołanie do istnienia pozostaje bowiem dziełem miłości mężczyzny i kobiety realizowanej w rodzinie ${ }^{5}$.

3 J. Mariański, Praktyki religijne a postawy prorodzinne młodzieży, w: Małżeństwo i rodzina w prawie kanonicznym, polskim i międzynarodowym, red. T. Płoski, J. Krzywkowski, Olsztyn, s. 37.

4 J. Bajda, Rodzina miejscem Boga i człowieka, Łomianki 2005, s. 44.

5 J. Bajda, Rodzina Bogiem silna, Łomianki 2005, s. 85. 
Pierwszą racją istnienia człowieka, zgodnie z nauczaniem Jana Pawła II, jest służba życiu, urzeczywistniająca się w błogosławieństwie Stwórcy. Płodność to owoc i znak miłości małżeńskiej, żywe świadectwo wzajemnego oddania się małżonków, która zwykle nie zacieśnia się jedynie do fizycznego zrodzenia dzieci, ale posiada też znacznie szerszy kontekst: moralny, duchowy, nadprzyrodzony ${ }^{6}$. To zadanie małżonkowie powinni wypełnić w poczuciu chrześcijańskiej odpowiedzialności i szacunku dla Boga. Biologicznie bowiem włączeni zostali w powstanie nowego życia, którego powinni strzec i wychować.

Każde życie powołane do istnienia domaga się odpowiedzialności, która przejawia się „w szacunku wobec każdego poczętego człowieka”7. Według Bajdy, „zrodzenie, będące darem życia, objawia się w Chrystusie jako dar Boga. [...] Zrodzenie w Chrystusie, które uzyskuje swoją prawdę w sakramencie chrztu, stawia człowieka w nadprzyrodzonej relacji do Ojca. To jest najgłębsza podstawa ludzkiego powołania"8.

Trzeba zatem uznać, że rodzice w darze prokreacji zachowują duchowy wymiar rozwoju społeczeństwa. Z jednej strony są pomostem, dzięki któremu jednostka znajduje swe miejsce w społeczeństwie, z drugiej zaś osobliwym, kolektywnym związkiem służącym realizacji zadań społecznych, zwłaszcza że „normalna rodzina nie jest rodziną przeszłości, lecz jest rodziną przyszłości, jeśli chcemy mieć przyszłość"9.

Rodzice odpowiedzialni za kształt społeczeństwa nie tylko uczestniczą w akcie biologicznego zrodzenia dziecka. Ich zadaniem jest również chronić i bronić życia poczętego. Za dar życia odpowiedzialne jest też państwo. W tym kontekście Jerzy Bajda napisał:

[...] musimy mieć świadomość, że to słabe i bezbronne życie jest narażone na wiele niebezpieczeństw i dlatego, jeżeli państwo jako system prawa i sprawiedliwości ma jakiś sens, to przede wszystkim ten, że staje w obronie najsłabszych i zagrożonych. Jest rzeczą konieczną, by były

6 Jan Paweł II, Adhort. Familiaris consortio (dalej FC), nr 28.

7 B. Mierzwiński, Odpowiedzialne rodzicielstwo, w: Słownik małżeństwa i rodziny, red. E. Ozorowski, Warszawa-Łomianki 1999, s. 314.

8 J. Bajda, Powołanie małżeństwa i rodziny, Łomianki 2010, s. 98.

9 J. Bajda, Listy z Mediolanu, "Sprawy Rodziny” 98 (2012) nr 2, s. 37. 
gwarantowane prawa tych najmniejszych, by były gwarantowane prawa ich rodzin, by była gwarantowana świętość i nietykalność przymierza małżeńskiego ${ }^{10}$.

Rodzina jako instytucja stojąca na straży życia w pełni odpowiada za rozwój życia ludzkiego, również w zakresie przystosowania do późniejszego funkcjonowania w społeczeństwie. Rodzice są pierwszymi nauczycielami i wychowawcami. Dlatego też życie ludzkie powinno być szanowane i chronione w sposób absolutny już od chwili poczęcia ${ }^{11}$. W Konstytucji duszpasterskiej o Kościele w świecie współczesnym Lumen gentium podkreślono potrzebę stawania się bliźnimi dla każdego człowieka, niezależnie od tego, kim on jest. Zabójstwo, w tym aborcja i podobne sprawy i praktyki, są czymś haniebnym; zakażając cywilizację ludzką, bardziej hańbią tych, którzy się ich dopuszczają, niż tych, którzy doznają krzywdy, i są jak najbardziej sprzeczne z czcią należną Stwórcy. ${ }^{12}$.

Bajda sytuując rodzinę w przestrzeni społecznej, wyraźnie zaznacza, że Bóg powierzył ludziom zadanie obrony życia i że trzeba je realizować w sposób godny człowieka. Życie bowiem jest najwyższym i najcenniejszym darem. Seksualna natura człowieka i ludzka zdolność płodzenia przewyższają wszystko, co istnieje na niższych stopniach życia, dlatego aktom właściwym życiu małżeńskiemu należy się wielki szacunek. Łączenie miłości z odpowiedzialnym przekazywaniem życia nie zależy wyłącznie od szczerej intencji. Winno ono być określone na podstawie kryteriów natury osoby, stojących na straży integralnego sensu wzajemnego obdarowania i prokreacji w kontekście prawdziwej miłości. Ludzie wierzący muszą pamiętać, że życie ludzkie i obowiązek jego przekazywania nie mogą być ograniczane tylko do ziemskiego czasu, lecz że zawsze odnoszą się do wiecznego przeznaczenia człowieka ${ }^{13}$.

W „rodzinie rodzi się człowiek, w rodzinie człowiek przychodzi na świat”14. W rodzinie otrzymywane życie przyjmuje również charakter społeczny, gdyż

10 J. Bajda, Uznanie praw dzieci poczętych jest miara demokracji, w: Ochrona i promocja rodziny, red. M. Kluz, J. Młyński, Sandomierz 2015, s. 196.

11 Por. Katechizm Kościoła katolickiego[ dalej: KKK], 2270.

12 Por. Sobór Watykański II, Konstytucja duszpasterska o Kościele w świecie współczesnym Gaudium et spes [dalej GS], $\mathrm{nr} 27$.

13 GS 51.

14 J. Bajda, Rodzina miejscem Boga i człowieka..., dz. cyt., s. 44. 
społeczeństwo nie istnieje bez rodziny. Według Normana Goodmana „żadne społeczeństwo nie przetrwa, jeśli nie będzie mogło sie rozmnażać. Ograniczenie aktywności seksualnej do związków rodzinnych to istotny sposób zapewnienia ciągłości społeczeństwa”15. Stąd też Bajda pisze: „temat życia jest niemal ukryty w antropologicznej i duchowej warstwie powołania rodziny jako szczególnej wspólnoty osób, określonej mianem komunii osób”16.

\section{Rodzina nauczycielką wychowania}

W ujęciu Jerzego Bajdy przedłużeniem etosu zrodzenia jest etos wychowania, który przenosi postawę służby życiu we wszystkie aspekty codziennego życia. Przede wszystkim wychowanie jest stworzeniem warunków osobowego $\mathrm{i}$ transcendentnego powołania do rozwoju osoby, z wykluczeniem instrumentalizacji. W tym znaczeniu osoba poddaje się w swym rozwoju kształtowaniu oraz wchodzi w relacje ludzkości jako suwerenny podmiot godności i praw ${ }^{17}$.

Rodzina jest pierwszą i jednocześnie najważniejszą grupą społeczną, która wpływa na jednostkę.

Rodzina bowiem, jako podstawowa i niezastąpiona wspólnota wychowawcza, jest środowiskiem stwarzającym najlepsze warunki do przekazywania wartości religijnych, społecznych i kulturowych, które pomagają człowiekowi w kształtowaniu własnej tożsamości. Zbudowana zaś na miłości i otwarta na dar życia, nosi w sobie przyszłość społeczeństwa. Jej niezwykle doniosłe zadanie polega na tym, że ma ona skutecznie przyczyniać się do budowania przyszłości, szczególnie poprzez wychowanie członków do życia w społeczeństwie ${ }^{18}$.

Rodzina pozostaje zatem najistotniejszą „cegiełką” budującą i jednoczącą różne wymiary ludzkiego funkcjonowania.

15 N. Goodman, Wstęp do socjologii, Poznań 2001, s. 163.

16 J. Bajda, Rodzina miejscem Boga i człowieka..., dz. cyt., s. 85.

17 J. Bajda, Etyka rodzinna, w: Słownik małżeństwa i rodziny, red. E. Ozorowski, WarszawaŁomianki 1999, s. 135.

18 J. Młyński, W kręgu aksjologii abiturientów Tarnowa, Tarnów 2008, s. 205. 
Rodzina ma swoje charakterystyczne cechy, „które różnią ją od różnych innych grup społecznych; ma swój intymny, wewnętrzny świat, niepowtarzalny. Jednocześnie jest grupą otwartą, nawiązującą kontakty z innymi grupami, wchłaniającą treść „wielkiego świata” i dostosowująca się do zmian. Jest „kolebką” rozwoju osobowości każdego członka, zwłaszcza dziecka"19.

Dlatego też nie tylko pozostaje najcelniejszą cegiełką w tkance społecznej, ale przede wszystkim uczestniczy w procesie socjalizacji pierwotnej i wtórnej. Skoro zaś uznawana jest za kolebkę wychowania, to stanowi niezastąpione miejsce, gdzie człowiek nie tylko ma warunki, ale też otrzymuje treści wychowania religijnego, kulturowego i społecznego ${ }^{20}$.

Charles H. Cooley kierując uwagę na istotę rodziny, jako pierwszy nadał jej określenie „grupa pierwotna”. W jego ujęciu rodzina jest to pierwsze środowisko, z którym dziecko ma styczność i która „przekazuje mu prymarne wzory postępowania"21, tak potrzebne do jego dalszego funkcjonowania. Stad też

rodzice jako pierwsi są odpowiedzialni za wychowanie swoich dzieci. Wypełniają tę odpowiedzialność najpierw przez założenie ogniska rodzinnego, w którym panuje czułość, przebaczenie, szacunek, wierność i bezinteresowna służba. Dom rodzinny zaś jest właściwym miejscem kształtowania cnót. Na rodzicach spoczywa poważna odpowiedzialność za dawanie dobrego przykładu ${ }^{22}$.

Zdaniem Jana Pawła II, rodzinę wiążą „ze społeczeństwem żywotne i ograniczone więzy, stanowi bowiem jego podstawę i stale zasila poprzez swe zadanie służenia życiu; w rodzinie przecież rodzą się obywatele i w niej znajdują pierwszą szkołę tych cnót społecznych, które stanowią o życiu i rozwoju samego społeczeństwa"23. W tym kontekście Bajda uznaje, iż społeczne uwarunkowania socjalizacji w rodzinie implikowane są permanentnym

19 J. Rembowski, Rodzina w świetle psychologii, Warszawa 1986, s. 30.

20 Por. J. Bajda, Rodzina miejscem Boga i człowieka..., dz. cyt, s. 245.

21 J. Młyński, Rodzina - dar miłości i życia. Socjologiczne aspekty rodziny, http://www.rodzina. ipjp2.pl (15.06.2016).

22 KKK 2223.

23 Jan Paweł II, Adhort. apost. Familiaris consortio, nr 42. 
budowaniem przez nią przyszłości swoich dzieci. Jako niezastąpiona wspólnota wychowawcza rodzina kształtuje $\mathrm{w}$ dorastającej młodzieży poczucie braterstwa, harmonii, godności, poszanowania życia, troski o innych, bezpieczeństwa, wartości sensotwórczych i narodowych, które z kolei pomagają w kształtowaniu rodzinnej, społecznej oraz narodowej tożsamości. Z tej też przyczyny miłość rodzicielska pozostaje bezwarunkową afirmacją uspołeczniania w sensie osobowym i historyczno-społecznym ${ }^{24}$.

Rodzina zatem jako nauczycielka wychowania społecznego uczy życia w społeczeństwie, przygotowuje - włączając w życie rodzinne, oraz uczy wspólnego rozwiązywania problemów. Warto dodać, że socjalizacja w środowisku rodzinnym w okresie, gdy dziecko dopiero uczy się wszystkiego, odbywa się poprzez naśladownictwo najbliższego grona, a następnie poprzez przekazywanie dzieciom akceptowanych w rodzinie norm i wartości oraz zasad. W rodzinie kładzione są podstawy pod całokształt procesu uspołeczniania. Wychowanie w rodzinie powinno odbywać się $\mathrm{w}$ taki sposób, aby nadać dziecku takie cechy, dzięki którym będzie potrafiło dokonywać wyboru etycznych postaw. Wiedza, jakiej dziecko nabywa w rodzinie, to w głównej mierze wiedza o współżyciu zbiorowym, zwyczajach, o sposobie, w jaki należy się zachowywać w danej sytuacji, przekazanie świadomości o moralności czy gospodarstwie domowym. Rolą rodziny jest także przygotowanie dziecka do wypełniania ról kobiety i mężczyzny. Trzeba zaznaczyć, że oprócz rodziców na proces socjalizacji dziecka wpływają także inni członkowie rodziny, jakimi są dziadkowie, rodzeństwo, wujkowie... W procesie socjalizacji ważną rolę pełni miłość, którą się obdarowują członkowie rodziny ${ }^{25}$.

Do najważniejszych czynników tkwiących w środowisku rodzinnym, które zapewniają prawidłowy rozwój i wychowanie dziecka do społecznego bytowania, wypada zaliczyć:

- świadomość wychowawczą rodziców,

- atmosferę w rodzinie, charakteryzującą się poczuciem więzi, umiejętnością współżycia i współdziałania, wzajemnym szacunkiem i zrozumieniem,

- wychowanie do miłości Ojczyzny, przywiązania do ziemi,

24 J. Bajda, Rodzina jako miejsce kształtowania się światopogladu, w: Słownik małżeństwa i rodziny, dz. cyt., s. 445.

25 Por. A. Skreczko, Uspołecznienie dziecka w rodzinie, „W służbie Miłosierdzia” (2007) nr 4, s. 1. 
- wychowanie do postaw patriotyzmu ${ }^{26}$,

- uczenie pozytywnej historii,

- kształtowanie w młodym pokoleniu postaw religijnych,

- umiejętność organizowania procesu wychowania i socjalizacji,

- umiejętność łączenia wychowania w rodzinie z innymi formami oddziaływania ${ }^{27}$.

Wskazane powyżej cele realizowane są $\mathrm{w}$ ramach funkcji socjalizacyjnej rodziny. Zakres oddziaływania socjalizacyjnego obejmuje m.in. wprowadzanie członków rodziny w szeroko rozumiane życie społeczne, język ojczysty, obyczaje, wzory zachowań i wartości kulturowe ${ }^{28}$.

\section{Rodzina przekazem tradycji}

Proces wychowania i socjalizacji niewątpliwie połączony jest z przekazem tradycji. Ten proces można nazwać pasem transmisyjnym wiary, obyczajów i tradycji. W tym kontekście Iwona Szczerbik stwierdza: „każda rodzina tworzy własną niepowtarzalną atmosferą życia domowego, na którą wpływają między innymi: stosunki wzajemne między małżonkami, miłość rodzicielska do dzieci, codzienne zachowania członków rodziny, kultywowanie tradycji, a także służba uznawanym wartościom"29.

Tradycje w rodzinie należy uznać za wewnętrzny element jej życia społecznego. W każdej bowiem rodzinie tradycja jest przekazywana na różne sposoby. W dużej mierze zależy od przyjętych wcześniej wzorów pokoleniowych. Zwykle jednak tradycja łączy się z postawami, świętami, i ukazuje

26 Według Bajdy przejawem prawdziwej i autentycznej miłości ojczyzny nie są tylko piękne i uroczyste deklaracje słowne, ale nade wszystko dobre czyny, postawy. Mają je charakteryzować solidna praca oraz wychowanie do dobra wspólnego. Wytrwała i ofiarna praca jest czynnikiem zapewniającym ojczyźnie pomyślność, dobrobyt, pokój oraz rozwój. To rodzaj służby pełen poświęceń, solidarności i podporządkowanie swoich interesów dobru ojczyzny. Por. S. Wyszyński, Służba matce ojczyźnie, w: Z dziejów polskiego patriotyzmu. Wybór tekstów, red. J. Kloczkowski, Kraków 2007, s. 320-333.

27 Por. H. Cudak, Znaczenie rodziny w rozwoju i wychowaniu małego dziecka, Warszawa 1999, s. $214-215$.

28 Por. W. Skarbek, Wybrane zagadnienia socjologii ogólnej i socjologii edukacji, Piotrków Trybunalski 2003, s. 108.

29 I. Szczerbik, Wpływ bezrobocia na funkcjonowanie rodziny polskiej, Cyt. za: J. Truskolaska, Atmosfera życia rodzinnego jako istotny element kultury wychowawczej rodziny, , Społeczeństwo i Rodzina" 19 (2009), nr 2, s. 93. 
tożsamość społeczną jednostki. Wypada uznać, iż międzypokoleniowy przekaz obyczajów, zwyczajów jest mechanizmem, który ukazuje ciągłość pokoleniową w zakresie przejawianych wartości (czyli wskazuje na podobieństwo między rodzicami a dziećmi). Proces ten polega na przekazywaniu ważnych dla rodziców obyczajów poprzez specyficzny kontakt ze swoimi dziećmi ${ }^{30}$.

Przekaz wiary i historii naszych przodków, uwarunkowany dziedzictwem pokoleń, zakorzeniony został jedynie w rodzinie. Bóg bowiem traktuje w sposób nierozdzielny powierzone rodzinie zadania, którymi są: „kształtowanie rodziny i panowanie nad światem oraz troska o życie, budowanie historii i tradycji "31.

Tradycja to suma procesów, zwyczajów, historii, przekazywanych z pokolenia na pokolenie ${ }^{32}$. Rodzina pozostaje centrum przekazywania tradycji, rodzice jako nauczyciele wychowują, pielęgnują zachowanie i utrzymanie tradycji. Dlatego też Jan Rembowski określił rodzinę jako

małą i jednocześnie pierwotną grupę o swoistej organizacji i określonym układzie ról między poszczególnymi członkami, związaną wzajemną odpowiedzialnością moralną, świadomą własnej odrębności, mającą swe tradycje i przyzwyczajenia, zespoloną miłością i akceptującą się nawzajem ${ }^{33}$.

Wypada dodać, że niezmiernie ważnym elementem wychowania w rodzinie jest przekaz wartości, tradycji i wspólnego świętowania historii, religijności, kultu przodków. Henryk Cudak podkreśla, iż

w obliczu zagrożenia współczesnej rodziny wewnętrzną atomizacją i osamotnieniem we własnej rodzinie oraz zanikiem tradycji i wartości

30 Por. H. Elżanowska, Międzypokoleniowa transmisja wartości w rodzinie , „Studia z Psychologii” (2012) nr 18, s. 107.

31 J. Bajda, Listy z Mediolanu, „Sprawy Rodziny” 98 (2012) nr 2, s. 41.

32 Tradycja to "słowo wieloznaczne, jednak we wszystkich licznych zastosowaniach, w mowie potocznej i w nauce, odnosi się ono do sprawy związków współczesności z przeszłością. W znaczeniu najszerszym tradycja oznacza to wszystko, czego pokolenia obecnie żyjące nie stworzyły dopiero co, same, lecz co zawdzięczają pokoleniom wcześniejszym (synonimem słowa tradycja jest w tym kontekście dziedzictwo kulturowe) lub własnej dawniejszej działalności (tradycja jako ustalony od dłuższego czasu sposób postępowania, nawyk, zwyczaj, rutyna). Idzie przy tym nie o osiągnięcia materialne, lecz o wartości, instytucje społeczne, sposób życia, wzory myślenia i postępowania". J. Szacki, Tradycja, w: Słownik spoteczny, red. B. Szlachta, Warszawa 2004, s. 1491.

33 J. Rembowski, Więzi uczuciowe w rodzinie, Warszawa 1972, s. 83. 
rodzinnych problem dialogu wewnątrzrodzinnego, wspólnego świętowania staje się elementem pierwszorzędnym w życiu domowym ${ }^{34}$.

Tradycje rodzinne stają się nie tylko wspólnym dialogiem życia najbliższych członków, ale też odpowiadają za spójność i więzi rodzinne. Więzi te mają charakter potrójny i odnoszą się do więzi małżeńskich, rodzicielskich oraz bratersko-siostrzanych. Właśnie wspólne spotkania, wspólne świętowanie, wspólne dbanie o przestrzeganie i pielęgnowanie tradycji rodzinnych to promieniowanie oraz umacnianie rodzinnych i społecznych relacji, wyrażanych w postawach i uczuciach.

Bajda odwołując się do tradycji w rodzinie, akcentuje jej sacrum. To właśnie wiara jest nośnikiem tradycji polskiej. Na tradycję polską, jak zauważa Bajda, składa się w

szczególnej mierze wszystko to, co w jakiś sposób dotyczy kultu, a więc relacji do Boga, Maryi i świętych. Święta obchodzone w Polsce odznaczają się bogato zapisaną tradycją. Święta Bożego Narodzenia mają wymowę rodzinności i ludzkiej solidarności. One zbliżają ludzi do siebie, ludzi czynią ludźmi i przez to obdarzają ich prawdziwym szczęściem. Również święto Zmartwychwstania Pańskiego ma specyficznie polską tradycję związaną z liturgią Wielkiego Tygodnia. W ten sam ciąg tradycji wpisuje wspomniany autor uroczystość Bożego Ciała i tradycje świąt maryjnych. Do zapisu należy włączyć także polskie kolędy, pieśni religijne, godzinki o Najświętszej Maryi Pannie. Z ducha narodu zrodziły się też śpiewane w Wielkim Poście Gorzkie żale, których nie ma gdzie indziej. One są polskimi lamentacjami nad cierpieniem Boga za nas i nad naszą wobec Niego niewdzięcznością, i w ciągu wieków były one źródłem duchowej siły dla Polaków wystawionych na tak trudne i bolesne próby dziejowe ${ }^{35}$.

Tradycja zachowywana i przekazywana przez rodzinę stanowi dziedzictwo i ogniwo łączące pokolenia. Dotyczy szczególnie obchodzenia świąt (Wigilia, Pascha, pamięć o zmarłych). Jest pewnego rodzaju kultem i legitymizacją

34 H. Cudak, Kształtowanie kultury pedagogicznej młodzieży w programach szkolnych, „Pedagogika Rodziny" (2011) nr 1, s. 1.

35 M. Kluz, Odpowiedzialność za Ojczyznę w zjednoczonej Europie w ujęciu księdza profesora Jerzego Bajdy, "Studia Gdańskie” (2016) nr 39, s. 196. 
wiary. W tym kontekście Jerzy Bajda zapisał: „Mamy swój honor i poczucie tożsamości, mamy swoją tradycję" ${ }^{36}$. Jednym z podstawowych zadań tradycji jest zapewnienie ciągłości i trwałości polskich świąt, polskich zwyczajów. Ponieważ tradycja jest odwołaniem się do przeszłości i zarazem troską o przyszłość, jawi się jako fundament rozwoju narodu ${ }^{37}$.

Bajda uważał, że rodzina jest miejscem Boga i człowieka. Dlatego też człowiek zajmuje szczególne miejsce w historii zbawienia. Bóg nie tylko mówi do człowieka, ale też objawia człowieka. Ten rodzaj relacji Bajda określa antropologią objawienia. Antropologia objawienia, zwana chrześcijańską, jest wewnętrznie powiązana z rzeczywistością rodziny. Rola rodziny zaś nie ogranicza się do jakiejś idei rozumianej po Platońsku, ale uzyskuje konkretną historyczną i egzystencjalną postać. Całą prawdę o sobie człowiek może realizować w Kościele poprzez wypełnienie powołania na poziomie społecznym, historycznym, osobowym w ramach pełnionych zadań, uwarunkowanych przekazem międzypokoleniowej tradycji (kult, zwyczaje, świętowanie, pamięć o przodkach) ${ }^{38}$. W społeczeństwie ów przekaz tradycji powinien opierać się na prawie miłości.

\section{Rodzina nauczycielką kultury}

W procesie socjalizacji w rodzinie nieodłącznie przekazywane są określone wzory kulturowe. Można rzec, iż w tej grupie następuje przekazanie zwyczajów i obyczajów, które określają tożsamość społeczno-kulturową i przekaz dziedzictwa kulturowego w rodzinie. Według J. Pruszyńskiego dziedzictwo kulturowe to zasób rzeczy nieruchomych i ruchomych wraz ze związanymi z nim wartościami duchowymi, zjawiskami historycznymi i obyczajowymi uznawanymi za podstawę ochrony prawnej dla dobra konkretnego społeczeństwa i jego rozwoju oraz dla przekazania ich następnym pokoleniom, z uwagi na zrozumiałe i akceptowane wartości historyczne, patriotyczne, religijne, naukowe i artystyczne, mające znaczenie dla tożsamości i ciągłości rozwoju politycznego, społecznego i kulturalnego, dowodzenia prawd

36 J. Bajda, Feministki, papież i Europa, w: Obrona i promocja rodziny, red. M. Kluz, J. Młyński, Sandomierz 2015, s. 36.

37 Por. J. Bajda, Ku odnowionej Polsce , „Sprawy Rodziny” (2006) nr 73/1, s. 96-97.

38 Por. J. Bajda, Rodzina miejscem..., dz. cyt., s. 10-11. 
i upamiętniania wydarzeń historycznych, kultywowania poczucia piękna i wspólnoty cywilizacyjnej ${ }^{39}$.

Należy dodać, że dziedzictwo kulturowe to nie tylko podstawa bytu materialnego. Dziedzictwem jest to wszystko, co stanowi duchowy wymiar bytu narodu. Polska - jak podkreślał ks. Bajda - to przede wszystkim dziedzictwo duchowe. Dlatego istotnym obowiązkiem obywateli jest troska o zachowanie tego dziedzictwa ${ }^{40}$. Adam Rodziński pisze:

prawdziwa kultura w podstawowym, filozoficznym (i teologicznym równocześnie) rozumieniu jest przede wszystkim uszlachetnieniem ludzkiej osoby, udoskonaleniem jej ducha. Ona też decyduje o „kulturalności” poszczególnych struktur kulturowych. Tylko przez partycypację w „kulturze osoby" poszczególne kultury i cywilizacje zdolne są osiągnąć tę rangę, do jakiej są powołane $e^{41}$.

Podmiotem przekazującym i zachowującym dziedzictwo kulturowe jest rodzina. W niej bowiem jak w lustrze odbijają się wszelkie zachowania związane z kontekstem kulturowym. W ten sposób rodzina pozostaje pierwszym miejscem miłości interpretowanej jako „układ wzajemnych stosunków, charakter więzi emocjonalnej, wzajemne traktowanie siebie przez członków rodziny, a w pierwszym rzędzie ustosunkowanie się rodziców do siebie nawzajem i do dzieci”42. Ten rodzaj misji rodziny trzeba analizować w kontekście duchowym i społecznym. Na poziomie duchowym przekaz kultury związany jest z zachowaniem wartości religijnych i moralnych, na poziomie społecznym zaś dotyczy wychowania patriotycznego i narodowego.

Socjalizacja dzieci i młodzieży powinna być zogniskowana wokół ducha kultury. Dlatego, jak wskazuje Bajda,

trzeba wrócić do tradycyjnej kultury, która wychodząc od rodziny i stosunków sąsiedzkich oraz szkoły, uczyła takiego sposobu obecności w świecie, który (sposób) opiera się na etyce cnoty; i ten właśnie styl działania

39 J. Pruszyński, Dziedzictwo kultury Polski: jego straty i ochrona prawna, Kraków 2001, s. 50.

40 Por. Jan Paweł II, Pamięć i tożsamość, Kraków 2005, s. 66.

41 A. Rodziński, Osoba, moralność, kultura, Lublin 1989, s. 231.

42 M. Tyszkowa, Badanie nad uspołecznieniem i osobowością dzieci jedynych i mających rodzeństwo, w: Rodzina a rozwój jednostki, red. M. Tyszkowa, Poznań 1990, s. 25. 
przenosił się następnie na fabryki, szkoły, szpitale, ośrodki administracji, banki i inne urzędy. Obecnie to dziedzictwo społeczne znajduje się w poważnym kryzysie, ponieważ rodziny usiłujące kontynuować te tradycje czują jakby wykonywały „pracę Syzyfa” i ulegają frustracji ${ }^{43}$.

Tymczasem aby przekazać dziedzictwo, kulturę, trzeba zaangażowania rodziny i osób, którym powierzono społeczny mandat zaufania i które posiadają wysoki status w narodzie. Kultura, jak zauważa Karol Wojtyła, musi ujmować istotę duchowo-osobowego życia ludzkiego, zarówno na płaszczyźnie jednostkowej, jak i społecznej ${ }^{44}$. Tylko rodzina jest miejscem kształtowania kultury chrześcijańskiej.

Zagadnienie to analizował Leon Dyczewski, którego zdaniem kultura uzewnętrznia się przez członków społeczeństwa i „pomaga członkom społeczeństwa dokonywać wyborów, ukierunkowuje i wskazuje cele oraz środki działania, a także wzmacnia samo działanie w ramach tej dziedziny kulturowej, w której sama tkwi”"45. Stąd też Bajda nauczał, iż ważnym elementem dziedzictwa jest historia narodu, którą człowiek powinien kochać, szanować i nigdy o niej nie zapominać ${ }^{46}$. Polska bowiem miała własną historię i tożsamość kulturową, w której zostały zachowane wartości chrześcijańskiej kultury ${ }^{47}$.

W nauczaniu Bajdy obok przekazywanego orędzia moralnego nie mogło zabraknąć przekazu prawdy o rodzinie, a szczególnie o zachowaniu tożsamości kulturowej. Rola rodziny w tym aspekcie jest nieoceniona. Rodzina bowiem jako fundament społeczeństwa stoi na straży przekazu kultury i wychowania do kultury. Dlatego też jej doniosła rola to misja kształtowania w społeczeństwie obywateli-chrześcijan, ludzi zdolnych do głębokiego szacunku, otwartych na rozwój państwa, którego podstawą jest rozwój wartości chrześcijańskich. Właśnie te wartości decydują o duchu kultury i cywilizacji miłości.

43 M. Tyszkowa, Badanie nad uspołecznieniem i osobowościq..., dz. cyt., s. 64.

44 Por. J. Bajda, Znaczenie rodziny dla kultury, w: Teologia, kultura, wspótczesność, red. Z. Adamek, Tarnów 1995, s. 41-62.

45 L. Dyczewski, Kultura polska w procesie przemian, Lublin 1995, s. 58.

46 Por. J. Bajda, Feministki, papież i Europa, dz. cyt., s. 37.

47 J. Bajda, Wokół pewnego sporu, w: Obrona i promocja rodziny, red. M. Kluz, J. Młyński, Sandomierz 2015, s. 94. 


\section{Rodzina środowiskiem przekazu wartości}

Budowanie właściwego systemu wartości powinno być przygotowaniem młodych ludzi do ich samodzielnego, niezależnego życia w istniejącym układzie społecznym, kulturowym i moralnym. Ważne są przy tym zarówno wartości najwyższe, jak i podstawowe, bez których pierwsze nie mogłyby istniećc ${ }^{48}$. Szczególnie atmosfera domu rodzinnego wpływa na kształtowanie się postaw i systemu wartości dzieci i młodzieży. Brak poczucia bezpieczeństwa, dialogu z rodzicami oraz niezaspokojona potrzeba miłości w dzieciństwie mogą prowadzić w przyszłości do zachowań destrukcyjnych młodych osób, które często szukają odpowiedzi na dręczące ich pytania. Młodych ludzi często cechują postawy egoistyczne, nastawieni są oni bardziej na branie niż dawanie. Nie wolno zapominać, że dzisiejsza młodzież wzrasta w społeczeństwie szybkich zmian. Współczesne młode pokolenie często ucieka od rzeczywistości, zaangażowania społecznego, politycznego, za to w większym stopniu interesuje się zaspokajaniem własnych potrzeb materialnych, konsumpcyjnych. Zagubienie w świecie wartości, brak właściwej hierarchii wartości czy wręcz wybór antywartości, które nie mogą być społecznie akceptowane, jest dzisiaj częstym problemem człowieka. Kształtowanie właściwej hierarchii wartości jest bardzo potrzebne, aby człowiek nie znalazł się w stanie dezorientacji aksjologicznej ${ }^{49}$.

Każdy człowiek ma określone cele i dążenia, które są przejawem systemu wartości i które pragnie realizować. Wartości motywują aktywność życiową człowieka, a także mobilizują w sytuacjach trudnych i stresowych. Wartości w pewnym stopniu określają indywidualny i społeczny kształt funkcjonowania człowieka. Odgrywają określoną rolę w określeniu materialno-cywilizacyjnych warunków ludzkiego życia. Pomoc udzielona drugiemu człowiekowi jest przejawem uznawania wartości prospołecznych. Również zaufanie do ludzi ma swoje podłoże w wartościach prospołecznych. Dzisiaj bardziej niż kiedykolwiek społeczeństwo potrzebuje autorytetów moralnych ${ }^{50}$, którzy

48 Por J. Młyński W kręgu aksjologii abiturientów Tarnowa, Tarnów 2008, s. 71.

49 Por. J. Młyński W kręgu aksjologii abiturientów Tarnowa, dz. cyt., s. 74.

50 ,Autorytet moralny przypisuje się zazwyczaj ludziom, a nie instytucjom. Pierwsze [znaczenie] dotyczy ludzi, którzy posiadają pewne szczególne cechy, które pozwalają pełnić im rolę nośnika norm kodeksu etycznego. W drugim znaczeniu autorytet odwołuje się do ludzi, którzy są zdolni ten kodeks etyczny dostosować do różnych wymogów życia. Rozumienie trzecie zakłada, że ludzie potrafią samodzielnie tworzyć normy postępowania, 
przywrócą dawny porządek świata, małżeństwa i rodziny, ponieważ ludzie czują się zagubieni bardziej niż kiedyś.

Rodzina wychowuje do wartości moralnych i narodowo-patriotycznych. Wychowanie moralne to „zbiór obyczajów danej społeczności lub jednostki ujemnych lub dodatnich, zasady głoszone przez jakiś system etyczny [...], charakterystyczny przymiot czynów ludzkich, pewne dobro idealne, które pozytywnie wpływa na osobę ludzką"51. Podstawowym zadaniem rodziców jest wychowanie dzieci do, przestrzegania dekalogu, nauczenie odróżniania dobra od zła, szacunku dla drugiej osoby, pielęgnacji wiary i miłości Kościoła.

Według Franciszka Adamskiego

rodzice uosabiają dla dzieci słuszne wzory postępowania, najwyższe wartości - i pod wpływem tych wartości kształtują się pojęcia etyczne, a także religijne.[...] Systemy wartości reprezentowane przez rodziców stanowią dla dzieci swoisty kodeks norm, określających, co dobre, a co złe, co wolno, a czego nie należy czynićs2 .

Stąd też zwykle normy moralne rodziców decydują o postawie dziecka w jego późniejszym rozwoju.

Z kolei wychowanie narodowo-patriotyczne urzeczywistnia się w procesie socjalizacji, w którym naród, ojczyzna, patriotyzm, państwo i pokój stanowią podstawowe ogniwa rozwoju człowieka. Bowiem miłość do narodu, ojczyzny, ,jak każda miłość czyni człowieka lepszym”" ${ }^{3}$.

W ujęciu Bajdy wychowanie patriotyczne jawi się jako umiłowanie ojczyzny. Jego zdaniem „wychowanie patriotyczne ma miejsce głównie w domu rodzinnym. Dom rodzinny odgrywa fundamentalną rolę w wychowaniu na wszystkich płaszczyznach, w tym szczególną w wychowaniu do miłości ojczyzny"54. Świadectwem tej miłości jest troska o rozwój gospodarczy, społeczny, kulturalny, intelektualny, oraz religijny i moralny.

które akceptowane zostają przez środowisko, w którym mieszkają". J. Młyński, W kręgu aksjologii abiturientów Tarnowa, dz. cyt., s. 257.

51 J. Mariański, Moralność, w: Encyklopedia pedagogiczna XXI wieku, t. III, Warszawa 2004, s. 408.

52 F. Adamski, Rodzina. Wymiar społeczno-kulturowy, Kraków 2002, s. 39.

53 K. Chałas, S. Kowalczyk, Wychowanie ku wartościom narodowo-patriotycznym, Lublin-Kielce 2006, s. 10.

54 M. Kluz, Odpowiedzialność za Ojczyznę w zjednoczonej Europie w ujęciu księdza profesora Jerzego Bajdy, "Studia Gdańskie” (2016) nr 39, s. 200. 
Wychowanie do miłości ojczyzny jest szczególny, zadaniem rodziców. $\mathrm{W}$ tym procesie rodzice powinni dbać o kształtowanie w dzieciach takich postaw , jak: życzliwość dla ludzi, szacunek dla starszych, uznawanie ich autorytetu, pomoc potrzebującym, sprawiedliwość i solidarność. Patriotyzm jest realizowany przez miłość. Miłość zaś - jak zauważał Bajda - „potwierdza się przez gotowość do ofiary" 55. Prawdę tą podkreślał wielokrotnie Prymas Tysiąclecia, stwierdzając: „musisz sobie postawić wielkie wymagania. Musisz wychowywać się w duchu ofiary i do ofiar się uzdalniać. Może bowiem przyjść taka chwila, w której tylko ofiarą będzie można zagwarantować wolność Ojczyźnie”56.

Rodzice w systemie społecznym jawią się jako jego podstawowe elementy. Od nich zależy wprowadzenie jednostki w kulturę narodową, tradycje i wartości. W procesie tym nie można zapomnieć o wychowaniu do wolności i miłości. Misją rodziny bowiem jest wskazanie właściwego rozumienia i przyjęcia miłości. Chodzi o to, aby miłości jako jednej z najważniejszych wartości nie uprzedmiotawiać i nie instrumentalizować. Miłość jest powołaniem. Trzeba pamiętać, że „wolność, miłość i powołanie znajdują głębokie zakorzenienie w samej stworzonej naturze osoby ludzkiej, chociaż doskonała synteza natury i łaski dochodzi do głosu dopiero dzięki Odkupieniu i dzięki wypełnieniu się Prawa w Chrystusie"57.

Wartości tak zinternalizowane w świadomości dzieci i dorastającej młodzieży stanowią nie tylko dynamiczny element kultury, ale nade wszystko są wyznacznikami postępowania człowieka wobec społeczeństwa. Obiektywnie rzecz biorąc, jak zauważa Jan Szczepański:

wartości są regulatorami ludzkich dążeń i postępowania, pozwalają na ocenę postępowania innych, służą jako podstawa oceny społecznej przydatności członków grup, a zatem wyznaczają zasady hierarchii społecznej i określają zasady współżycia społecznego ${ }^{58}$.

Reasumując, warto dodać, że rodzina od zawsze była pierwszą szkoła życia. Jej rola jest doniosła i znacząca. Bez rodziny nie ma wychowania, nie

55 J. Bajda, Rodzina miejscem Boga i człowieka..., dz. cyt., s. 152.

56 S. Wyszyński, Bez ofiar i wyrzeczeń nie ma zwycięstw (16.08.1970), w: Nauczanie społeczne 1946-1981, Warszawa 1990, s. 415.

57 J. Bajda, Rodzina miejscem Boga i człowieka..., dz. cyt., s. 270.

58 J. Szczepański, Elementarne pojęcia socjologii, Warszawa 1970, s. 45. 
ma też kształtowania postaw moralnych i narodowych. Tylko w niej człowiek staje się bogatszy kulturowo, społecznie, staje się bogatszym człowiekiem, „wchodzi na drogę dobra, jakie jest wpisane w jego serce" 59 .

\section{Podsumowanie}

Każdy człowiek rodzi się i wzrasta w określonym środowisku społeczno-kulturowym, ale też jest kreatorem w społeczeństwie kultury i wartości, które uprzednio przyswoił na drodze socjalizacji. Stąd też kształtowanie w rodzinie postaw wobec społeczeństwa jest jej istotnym obowiązkiem i zadaniem. Dlatego też rodzinę określa się jako „szkołę bogatszego człowieczeństwa” ${ }^{60}$.

Rodzina zawsze była strażniczką życia i miłości, miejscem i symbolem strzeżenia oraz obrony cennych wartości, w tym rodzinnych tradycji, obyczajów, patriotyzmu, religii, dziedzictwa kulturowego. Powiedzenie rodzina moją twierdzą jest nadal aktualne, chociaż niektórzy chcieliby uznać je za anachronizm. Rodzina wciąż pozostaje pierwszym miejscem budowania społeczeństwa. Ta jej misja jawi się jako znak czasu, a realizuje się poprzez dar życia, edukację, przekaz tradycji, religii, kultury i innych wartości, gdyż „między rodziną a narodem istnieje żywotna więź" ${ }^{61}$.

Trzeba jednak przyznać, że

budowanie demokracji, poszanowanie praw człowieka, odbudowa kultury i moralności, kształtowanie postaw prospołecznych, przedsiębiorczości i odwagi wprowadzenia innowacji musi rozpocząć się w rodzinie. Nie zbuduje się demokratycznego społeczeństwa, jeśli w rodzinie nie będzie życzliwości wobec odmiennych poglądów i opinii, a siła argumentów będzie zamieniana na argumenty siły: zwłaszcza wobec słabszych. Nie odbuduje się kultury pracy, jeśli rodzice będą dzieciom przekazywać wzory życiowego cwaniactwa i pracowniczej nieuczciwości. Podobnie jest z zaangażowaniem na rzecz dobra wspólnego, które musi przekroczyć próg rodzinnego egoizmu, czy z polską religijnością, dla której szansą

59 J. Paweł, List do rodzin, nr 5.

60 M. Ozorowski, Rodzina szkołą bogatszego człowieczeństwa, „Studia nad Rodziną” (2013) nr 1 (32), s. 67.

61 J. Bajda, Rodzina miejscem Boga i człowieka..., dz. cyt., s. 156. 
na przyszłość jest pełniejsze odzwierciedlenie w moralności społecznej i rodzinnej, prywatnej i publicznej ${ }^{62}$.

Rodzina bowiem, jak zauważył Jerzy Bajda, jest „źródłem istnienia i żywotności narodu"63.

62 W. Świątkiewicz, Rodzina jako wartość w tradycji kulturowej Górnego ślqaska, w: Rodzina w województwie katowickim. Opracowania i raporty, red. W. Świątkiewicz, Katowice 1998, s. 10.

63 J. Bajda, Rozpad "humanizmu” oświeceniowego czy "katastrofa antropologiczna”, „Sprawy Rodziny" 73 (2006) nr 1, s. 90. 